\title{
Molecular cloning and characterization of chitinase genes from Streptomyces lividans 66
}

\author{
Kiyotaka Miyashita, ${ }^{*}$ Takeshi Fujil and Yasuo Sawada \\ National Institute of Agro-Environmental Sciences, 3-1-1 Kan-nondai, Tsukuba, Ibaraki 305, Japan
}

(Received 5 March 1991; revised 23 May 1991; accepted 3 June 1991)

\begin{abstract}
In order to study the genetic control of chitinolytic activity in Streptomyces, chitinase genes were cloned from $S$. lividans TK64 into the multicopy plasmid pIJ702 and their expression monitored in their natural host by measuring increases in chitinase productivity. Four independent clones were obtained, and the plasmids named pEMJ1, pEMJ5, pEMJ7 and pEMJ8. Restriction endonuclease digestion showed that although two of the plasmids (pEMJ7 and pEMJ8) shared a common DNA fragment, there were no substantial similarities between the inserts of plasmids pEMJ1, pEMJ5 and pEMJ7. This was confirmed by DNA-DNA hybridization studies. Four chitinases (A, B, C, and D) were identified, with molecular masses of 36, 46, 65, and $41 \mathrm{kDa}$, respectively. Production of chitinases $A$ and $B$ was specified by the plasmids pEMJ1 and pEMJ5, respectively. Genes for the other two chitinases (C and D) were carried by plasmid pEMJ7. Although significant differences were observed between chitinases $\mathrm{A}, \mathrm{B}$, and $\mathrm{C}$ in terms of optimum $\mathrm{pH}$ for activity and mode of digestion of substrates, chitinases $\mathrm{C}$ and D were very similar in these respects. Cloned genes were also expressed in $S$. coelicolor M130 and in Escherichia coli.
\end{abstract}

\section{Introduction}

Streptomyces are Gram-positive bacteria that are numerous in most soils. They derive a large part of their nutrition from insoluble organic debris by the action of a variety of extracellular hydrolytic enzymes. Chitin (poly$\beta-1,4-N$-acetylglucosamine) is abundantly distributed in nature as a major component of the cell walls of most fungi, the skeletons of invertebrates, and the shells of crustaceans. Chitinases (EC 3.2.1.14) are enzymes capable of hydrolysing chitin, and they are produced by various micro-organisms which include actinomycetes (Berger \& Reynolds, 1958; Reynolds, 1954; Tominaga \& Tsujisaka, 1976), other bacteria (Clarke \& Tracey, 1956; Monreal \& Reese, 1969; Watanabe et al., 1990), and yeast (Correa et al., 1982; Elango et al., 1982). Streptomyces are well known as decomposers of chitin, and chitin-containing media have been used for the selective isolation of Streptomyces (Gooday, 1990; Lingappa \& Lockwood, 1962).

Bacterial chitinase genes have been cloned from Serratia marcescens (Fuchs et al., 1986; Jones et al., 1986), Serratia liquefaciens (Joshi et al., 1988) and Vibrio

Abbreviations: 4-MU, 4-methylumbelliferyl. vulnificus (Wortman et al., 1986). Streptomyces chitinases have been the subjects of several reports (Beyer \& Diekmann, 1985; Hara et al., 1989; Kamei et al., 1989). Their synthesis can be induced by the presence of chitin and repressed by glucose. The cells seem to produce several different chitinases simultaneously. A gene for chitinase has been cloned from $S$. plicatus in $E$. coli (Robbins et al., 1988). However, our understanding of the regulatory mechanisms that control the synthesis and function of the multiple enzymes is far from complete. Isolation of multiple genes for chitinases is anticipated, and a study of the expression of chitinase genes in the homologous host is necessary so that more detailed information on the chitinase system can be obtained. In this report, we describe the cloning of genes from $S$. lividans that specify the production of four chitinases.

\section{Methods}

Bacterial strains and plasmids. Streptomyces lividans 66 (strains TK24 and TK64), S. coelicolor A3(2) strain M130, and Streptomyces plasmid pIJ702 (Hopwood et al., 1985) were kindly supplied by Dr D. A. Hopwood (John Innes Institute, Norwich, UK). Plasmids pUC18 and 19 were used for cloning in E. coli JM109 (Yanisch-Perron et al., 1985).

Media and culture conditions. YEME and R2YE medium were used for culture of mycelium prior to generation of protoplasts and for 
regeneration after transformation of Streptomyces, respectively (Hopwood et al., 1985). Streptomyces strains carrying recombinant plasmids were grown in the presence of thiostrepton $\left(50 \mu \mathrm{g} \mathrm{ml}^{-1}\right)$. Thiostrepton was a generous gift from Mr S. J. Lucania (E. R. Squibb \& Sons, Princeton, NJ, USA). For the production of chitinases, Streptomyces cultures were grown on inorganic-salts colloidal chitin medium [as broth or solidified with $1.5 \%(\mathrm{w} / \mathrm{v})$ agar] which contained $\left(\mathrm{g} \mathrm{I}^{-1}\right)$ : $\mathrm{K}_{2} \mathrm{HPO}_{4}(0 \cdot 7), \mathrm{KH}_{2} \mathrm{PO}_{4}(0.3), \mathrm{MgSO}_{4}(0 \cdot 5), \mathrm{FeSO}_{4}(0 \cdot 01), \mathrm{NH}_{4} \mathrm{NO}_{3}$ $(0 \cdot 3)$ and colloidal chitin (1.5). Colloidal chitin was prepared by the method of Lingappa et al. (1962). Proline (37 $\left.\mu \mathrm{g} \mathrm{ml}^{-1}\right)$ was added to the medium for the growth of Streptomyces lividans TK64 (Hopwood et al., 1985). For regulatory studies on expression of cloned genes, the modified minimal medium (NMMP) of Hopwood et al. (1985), which contains $0.5 \%$ Casamino acids was used. Luria broth and Luria agar were also employed (Maniatis et al., 1982).

Enzyme assay. 4-Methylumbelliferyl $N, N^{\prime}$-diacetyl chitobiose (4$\mathrm{MU}-(\mathrm{GlcNAc})_{2}$ ) and 4-MU $N, N^{\prime}, N^{\prime \prime}$-triacetyl chitotriose (4-MU(GlcNAc) $)_{3}$ ), (Sigma) were used as substrates (Roberts \& Cabib, 1982). For Streptomyces, culture supernatant was used as the source of enzyme. For $E$. coli, cells were disrupted by sonication (ultrasonic cell disruptor model MS-50, Heat Systems-Ultrasonics Inc., New York) for $10 \times 30 \mathrm{~s}$, centrifuged, and the supernatant used. Samples $(25 \mu \mathrm{l})$ were added to a reaction mixture which consisted of $450 \mu$ l substrate solution (60 $\mu \mathrm{M}-4-\mathrm{MU}$-disaccharide or $25 \mu \mathrm{M}$-4-MU trisaccharide) and $25 \mu \mathrm{l}$ $0.5 \mathrm{M}$-Tris/ $\mathrm{HCl}\left(\mathrm{pH} \mathrm{6.8)}\right.$. The mixture was incubated at $37^{\circ} \mathrm{C}$, and the reaction stopped after $10 \mathrm{~min}$ by the addition of $1 \mathrm{ml} 100 \mathrm{mM}-$ potassium phosphate/ $\mathrm{NaOH}$ buffer ( $\mathrm{pH} 11 \cdot 0)$. The amount of 4-MU liberated was measured by spectrofluorometry (model FP550, Japan Spectroscopic Co., Tokyo, Japan), with excitation at $360 \mathrm{~nm}$ and emission at $450 \mathrm{~nm}$. One unit of chitinase activity was defined as the amount of enzyme that liberated $1 \mu \mathrm{mol}$ 4-MU from the substrate in one minute at $37^{\circ} \mathrm{C}$. The effects of $\mathrm{pH}$ on chitinase activity were determined in $0.5 \mathrm{M}$ modified universal buffer (Skujins et al., 1962) (pH 2.5-5.1) and $0.5 \mathrm{M}$-Tris/malate buffer (pH 5.1-9.0).

Total cell protein assay. Total cell protein assay was carried out following the method of Virolle \& Bibb (1982).

Preparation of DNA. Chromosomal DNA from S. lividans was prepared by the method of Chater et al. (1982). Plasmid DNA was extracted by the method of Kieser (1984). Plasmid DNA used as a cloning vector (pIJ702) was further purified by ultracentrifugation through CsCl-ethidium bromide gradients (Maniatis et al., 1982). All recombinant DNA procedures were carried out as described by Maniatis et al. (1982).

Construction of a genomic library. pIJ702 was digested with $B g / \mathrm{II}$ and treated with calf intestinal alkaline phosphatase in accordance with the instructions supplied by the manufacturer (Boehringer). Chromosomal DNA from S. lividans TK64 was partially digested with Sau3AI and was then subjected to ultracentrifugation on a sucrose gradient (Maniatis et al., 1982). DNA fragments of 5-20 kb in size were collected, mixed with pIJ702 that had been treated with BgIII and dephosphorylated, and then the fragments were ligated with T4 DNA ligase. Formation of protoplasts and transformation were carried out by the method of Hopwood et al. (1985). S. lividans TK64 was used as the cloning host for initial transformation. Transformed protoplasts were regenerated on R2YE plates overlaid with soft nutrient agar that contained thiostrepton. Colonies were replica-plated onto inorganicsalts colloidal chitin agar supplemented with thiostrepton, and tested for production of chitinase.

Hybridization study. Plasmid DNA (100 ng) from each clone was dotblotted onto nylon membrane (Hybond N, Amersham). DNA fragments used as probes are shown in Fig. 1. Probes were prepared by labelling with ${ }^{32} \mathrm{P}$ by nick-translation (nick-translation । kit;. Takara
Shuzo Co., Ltd, Kyoto, Japan). Hybridizations were performed as described by Hopwood et al. (1985).

Electrophoresis. SDS-PAGE gels $(12 \%, \mathrm{w} / \mathrm{v})$ were purchased from Funakoshi Chemicals (Tokyo, Japan), and electrophoresis was carried out in accordance with the instructions supplied by the manufacturer. After electrophoresis, gels were stained with Coomassie Brilliant Blue $\mathbf{R}$ or $\mathrm{G}$. To estimate the molecular masses of proteins, a marker protein kit (MW-SDS-70; Sigma) was used for calibration. Isoelectric focusing on acrylamide slab gels was performed using the PhastSystem (Pharmacia) and preformed gels (PhastGel), in accordance with the instructions supplied by the manufacturer. Protein standards (Protein Test Mixture 9) were purchased as a kit from Serva.

Purification of chitinases. Cultures were grown to the early stationary phase at $30^{\circ} \mathrm{C}$ with vigorous shaking, at which time maximum activity was obtained. The culture filtrates $(500 \mathrm{ml})$ were lyophilized and the residue dissolved in $10 \mathrm{ml}$ distilled water. The solutions were desalted and equilibrated with $20 \mathrm{mM}$-Tris/ $\mathrm{HCl}$ buffer ( $\mathrm{pH} \mathrm{8.2)} \mathrm{in} \mathrm{an} \mathrm{ultrafiltra-}$ tion cell (model 8050, Amicon) and used as crude enzyme. Anionexchange chromatography was performed using a FPLC system from Pharmacia. An aliquot of the crude solution of enzyme $(500 \mu \mathrm{l})$ was chromatographed on a prepacked anion-exchange column, Mono $Q$ HR5/5 (5 mm i.d. $\times 50 \mathrm{~mm}$ ), which was equilibrated with $20 \mathrm{mM}$ $\mathrm{Tris} / \mathrm{HCl}$ buffer. The enzymes were eluted with a linear concentration gradient of $\mathrm{NaCl}(0-0.5 \mathrm{M})$ in the same buffer. Fractions of $0.5 \mathrm{ml}$ were collected.

\section{Results}

\section{Molecular cloning of chitinase genes from S. lividans}

A genomic library for $S$. lividans TK64 was constructed and about 4000 thiostrepton-resistant (Thir) transformants were obtained on R2YE plates containing this antibiotic. Plasmid DNA was isolated from randomly selected transformants, and checked for the insertion of foreign DNA. Approximately $90 \%$ contained an insert in the BglII site of pIJ702. Transformants were replicaplated onto inorganic-salts colloidal chitin plates supplemented with thiostrepton. After growth for 4-5 d at $30{ }^{\circ} \mathrm{C}$, a large clear zone, representing the decomposition of colloidal chitin, appeared around colonies of some of the transformants. However, after a week, most of the transformants exhibited the ability to decompose chitin. Ten transformants showing high chitinase activity at the early days of growth were selected, transferred to inorganic-salts colloidal chitin liquid medium and assayed for production of chitinase. The supernatant of five transformants showed an increase in chitinase activity of more than 10-fold when compared with that of the parent strain $S$. lividans TK64. Plasmid DNAs were isolated from these clones and reintroduced into $S$. lividans TK64 by transformation. After retransformation, one of the plasmids exhibited instability, and about a half of the transformed colonies showed only low levels of chitinase activity. The other plasmids, named pEMJ1, 
Plasmid

Phenotype

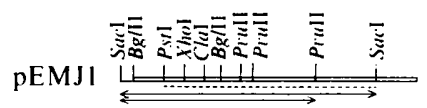

A

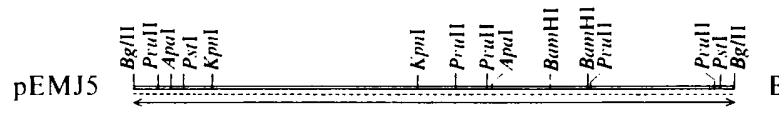

B

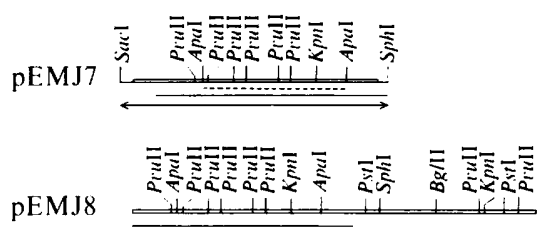

C, D

C, D

$1 \mathrm{~kb}$

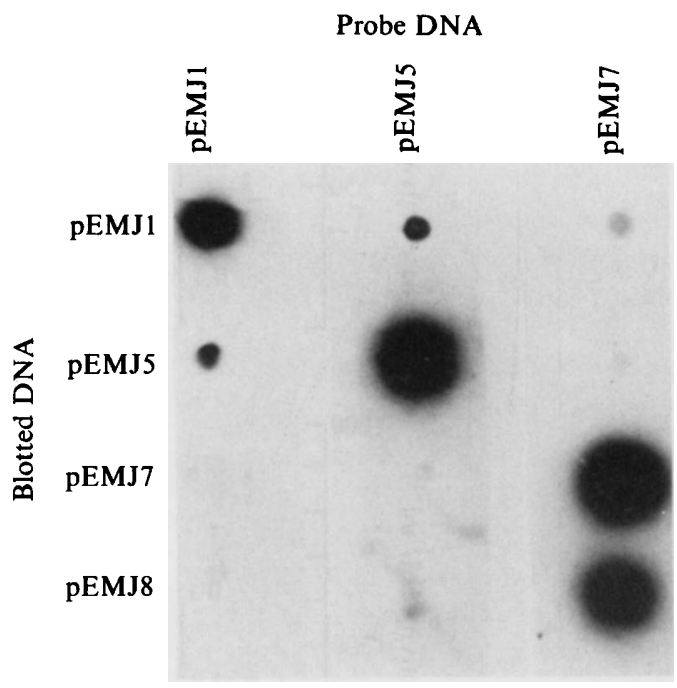

Fig. 2. Dot-blot hybridization analysis of inserted DNA in recombinant plasmids. Probes were ${ }^{32} \mathrm{P}$-labelled fragments of DNA from pEMJ1, pEMJ5, and pEMJ7, as indicated in Fig. 1.

MU from 4-MU disaccharide more rapidly than from 4MU trisaccharide. By contrast, transformants with pEMJ7 and pEMJ8 degraded 4-MU trisaccharide preferentially. The chitinases produced by the parent strain and by the transformants were purified and the results are shown in Fig. 3. The elution patterns of enzymes generated by each clone differed greatly from one another, and four peaks of chitinase activity were observed. Each peak of enzyme activity correlated to a peak of protein. Peaks I and II were prominent in the elution profile for the cells transformed with pEMJ1 and pEMJ5, respectively. Other peaks (III and IV) were most noticeable in the analysis of the supernatant of the cells transformed with pEMJ7. Material from each peak fraction was subjected to SDS-PAGE, and a single band was observed (Fig. 4). The chitinases corresponding to peaks I, II, III, and IV were named A, B, C, and D, respectively. The molecular masses of chitinases A, B, C, and $\mathrm{D}$, were estimated to be $36,46,65$ and $41 \mathrm{kDa}$, respectively, although we could not exclude the possibility that some plasmids carry truncated genes. Each plasmid was thus shown to increase the production of a particular chitinase.

\section{Expression of cloned genes for chitinase in $S$. coelicolor} A3(2) and E. coli

To confirm that we had indeed cloned structural genes for chitinase, the recombinant plasmids, pEMJ1, pEMJ5, pEMJ7, and pEMJ8, were introduced into $S$. coelicolor :M130 by transformation. Although plasmid 

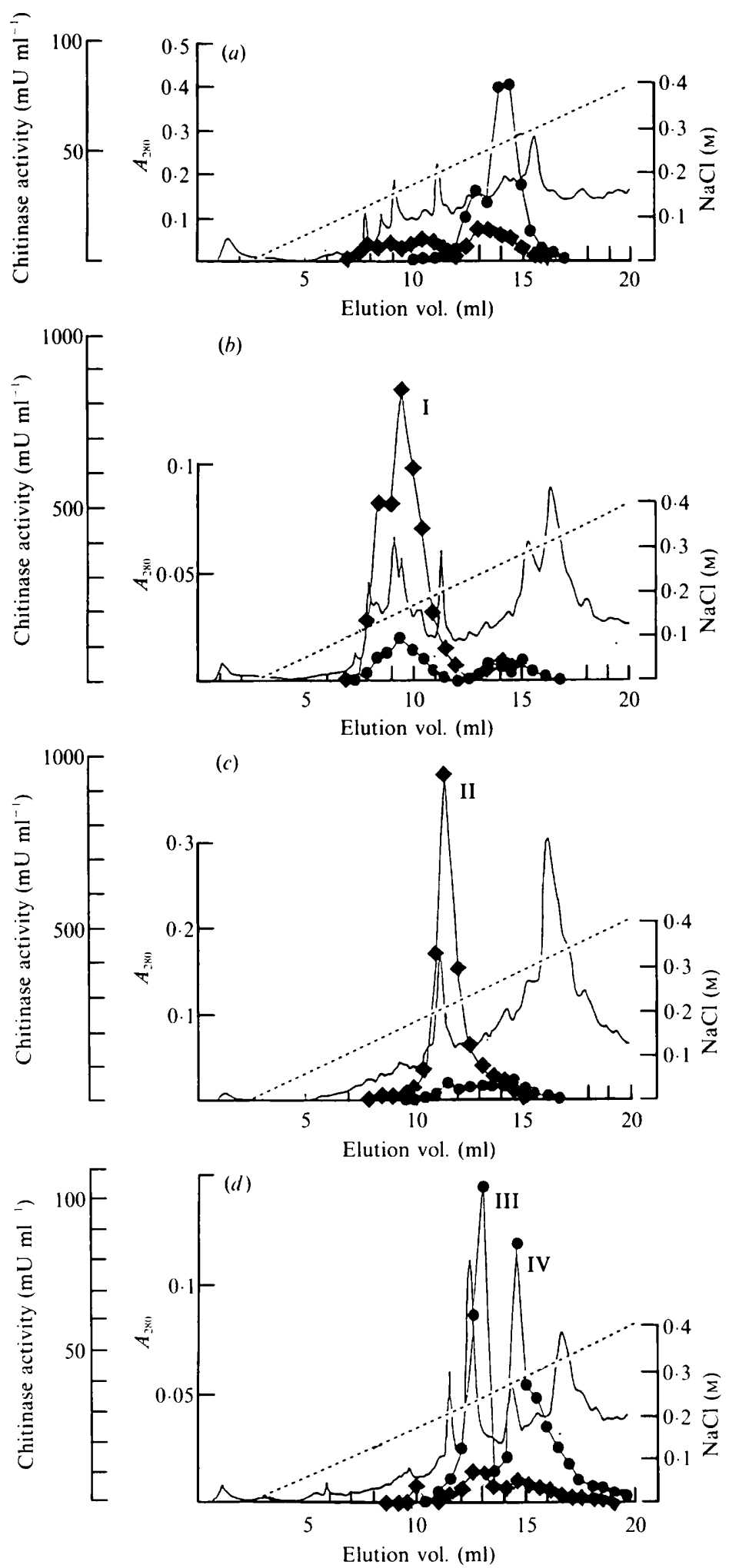

Fig. 3. Elution profile of crude enzymes after FPLC. (a) Elution profile of proteins secreted from $S$. lividans TK64. $(b, c, d)$ Elution profiles of proteins from $S$. lividans carrying plasmids pEMJ1, pEMJ5 and pEMJ7, respectively. Solid line, $A_{280} ; \diamond$, chitinase activity against 4MU disaccharide;, chitinase activity against 4-MU trisaccharide; dotted line, $\mathrm{NaCl}$ concentration. 
Table 1. Synthesis of chitinase in S. coelicolor M130

\begin{tabular}{lcc}
\hline \hline & \multicolumn{2}{c}{$\begin{array}{c}\text { Rate of 4-MU formation } \\
\left(\mu \mathrm{mol} \mathrm{min}^{-1} \mathrm{ml}^{-1}\right) \text { from }\end{array}$} \\
\cline { 2 - 3 } $\begin{array}{c}\text { Strain } \\
\text { (plasmid) }\end{array}$ & 4-MU(GlcNAc) & 4-MU(GlcNAc) \\
\hline M130 & 11 & 9 \\
M130(pEMJ1) & 110 & 20 \\
M130(pEMJ5) & 103 & 11 \\
M130(pEMJ7) & 18 & 122 \\
\hline \hline
\end{tabular}

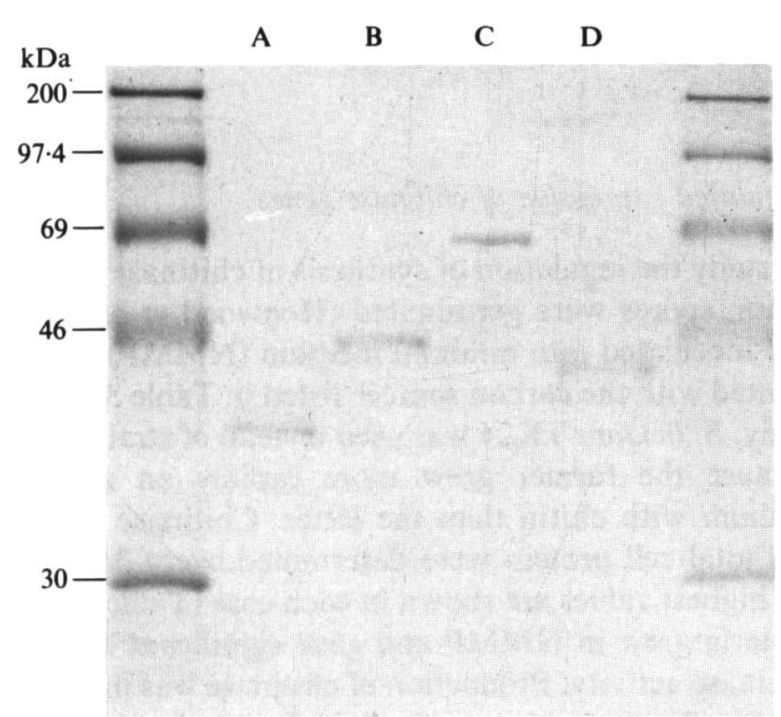

Fig. 4. SDS-PAGE of purified chitinases from the supernatant of cultures of $S$. lividans TK64 transformed with pEMJ1 (chitinase A), pEMJ5 (chitinase B) and pEMJ7 (chitinases C and D) and grown in inorganic-salts colloidal chitin liquid medium. Molecular mass markers are indicated.

pEMJ8 was unstable in $S$. coelicolor, the other plasmids were maintained stably in this strain. Table 1 showed that strains transformed with each plasmid exhibited about 10-fold increase in chitinase activity as compared to untransformed $S$. coelicolor M130. Furthermore, the strains transformed with pEMJ1 and pEMJ5 degraded 4-MU disaccharide more rapidly than 4-MU trisaccharide, and the strain transformed with pEMJ7 showed the opposite specificity. These results were in accordance with those observed with transformants of $S$. lividans. Total extracellular protein from each strain was subjected to SDS-PAGE, together with purified chitinases A, B, $\mathrm{C}$, and D (Fig. 5). The protein bands that corresponded to chitinases A and B appeared in the analysis of strains transformed with pEMJ1 and pEMJ5, respectively. The transformants with $\mathrm{pEMJ} 7$ generated bands identical to those of chitinases $C$ and $D$. In addition to the corresponding chitinase bands, there appeared additional bands in profiles of all the transformants. From their molecular masses, at least some of them were thought to correspond to thiostrepton-inducible proteins found in S. lividans by Murakami et al. (1988).

The SacI fragment of pEMJ1, the entire inserted fragment of pEMJ5, and the SacI-SphI fragment of pEMJ7 (Fig. 1) were generated and cloned into pUC18 and 19. The cultures were sonicated and centrifuged, and the resulting supernatants were assayed for chitinase activity. Cell lysates of $E$. coli harbouring the pUC plasmids containing either the $B g / \mathrm{II}$ fragment of pEMJ5 or the $S a c I-S p h I$ fragment of $\mathrm{pEMJ} 7$ showed significant levels of chitinase activity, although the activity of the cells containing the pEMJ7-derived fragment was much higher than that of the others. The chitinase activities were observed irrespective of the orientation of the cloned fragment with respect to the lac promoter on the pUC vector, showing that the chitinase genes were probably expressed from their own promoters. Subcloning of the SacI fragment of pEMJ1 into pUC18, giving either orientation with respect to the lac promoter, showed no chitinase activity at all. However, when the $3.1 \mathrm{~kb}$ SacI-PvuII fragment of pEMJ1 was subcloned into the SmaI-SacI sites of pUC18 and 19, chitinase activity was observed, but only in the pUC19-derived plasmid. Hence we conclude that expression of the chitinase gene on pEMJ1 in E. coli did not occur from its own promoter, but from that of lacZ. These results clearly demonstrated that we had indeed cloned genes from $S$. lividans that specified the production of four

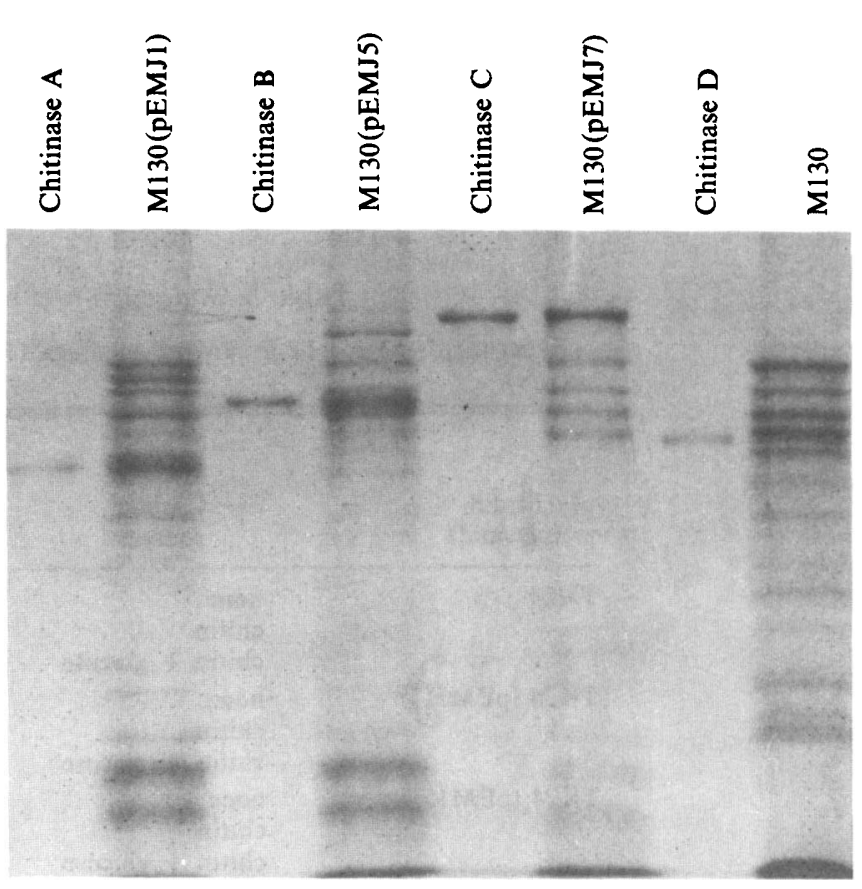

Fig. 5. SDS-PAGE of total extracellular proteins from $S$. coelicolor M130, with and without recombinant plasmid, together with chitinases purified from $S$. lividans TK64. 
Table 2. Gomparison of properties of cloned chitinases

\begin{tabular}{lccccc}
\hline \hline & \multicolumn{5}{c}{ Properties } \\
\cline { 2 - 6 } $\begin{array}{c}\text { Chitinase } \\
\text { (plasmid) }\end{array}$ & $\begin{array}{c}\text { Mol mass } \\
(\mathrm{kDa})\end{array}$ & $\begin{array}{c}K_{\mathrm{m}}{ }^{*} \\
(\mu \mathrm{M})\end{array}$ & $\begin{array}{c}\text { Optimal } \\
\mathrm{pH}\end{array}$ & $\begin{array}{c}\text { Activity ratio } \\
(2 \mathrm{~m} \text { ) } / 3 \mathrm{mer})\end{array}$ & $\mathrm{pI}$ \\
\hline Peak I (pEMJ1) & 36 & $36 \cdot 0$ & 3.0 & $7 \cdot 1$ & $4 \cdot 3$ \\
Peak II (pEMJ5) & 46 & $65 \cdot 0$ & $5 \cdot 0$ & 15 & $4 \cdot 1$ \\
Peak III (pEMJ7) & 65 & $4 \cdot 0$ & $6 \cdot 5$ & $0 \cdot 18$ & $4 \cdot 4$ \\
Peak IV (pEMJ7) & 41 & $4 \cdot 0$ & 6.5 & $0 \cdot 17$ & $4 \cdot 0$ \\
\hline \hline
\end{tabular}

* 4-MU-triacetylchitotrioside was used as substrate.

† Relative chitinase activity when 4-MU- $N$-acetylchitooligosaccharide was used as substrate.

chitinases. Differences in the expression of the cloned genes in $E$. coli may reflect differences in their promoter sequences.

\section{Characterization of cloned chitinases}

The properties of the chitinases were compared (Table 2). None hydrolysed 4-MU monosaccharide. Chitinases $\mathrm{A}$ and $\mathrm{B}$ generated 4-MU from 4-MU disaccharide more rapidly than from 4-MU trisaccharide, while the other two showed the opposite specificity. Chitinases $\mathrm{C}$ and $\mathrm{D}$ had lower $K_{\mathrm{m}}$ values against 4-MU trisaccharide than those of chitinases $\mathrm{A}$ and $\mathrm{B}$. The optimal $\mathrm{pHs}$ varied from 3.0 for chitinase $A$ to 6.5 for chitinases $C$ and D. Little difference was observed in the isoelectric points of the enzymes. It is clear that chitinases $C$ and $D$ are very similar in terms of optimal $\mathrm{pH}$, ratio of activities against 4-MU disaccharide and 4-MU trisaccharide, and $K_{\mathrm{m}}$ for 4-MU trisaccharide.

\section{Regulated expression of chitinase genes}

To study the regulation of synthesis of chitinase by each strain, spores were germinated (Hopwood et al., 1985) and inoculated into minimal medium (NMMP) supplemented with the carbon sources listed in Table 3. In this study, S. lividans TK24 was used instead of strain TK64 because the former grew more rapidly on minimal medium with chitin than the latter. Chitinase activity and total cell protein were determined every $24 \mathrm{~h}$, and the highest values are shown in each case (Table 3 ). The bacteria grew in NMMP and gave significant levels of chitinase activity. Production of chitinase was markedly increased by the addition of colloidal chitin in every case. Addition of glucose suppressed the synthesis of chitinase almost completely. A suppressive effect was also observed with glycerol (data not shown). The results suggest that the cloned genes were induced in the presence of chitin and repressed in the presence of readily utilizable carbon sources.

Table 3. Induction and repression of chitinase synthesis

Experiments were done in NMMP medium. Chitin was added at $0.15 \%$. Glucose was added at $1 \%$ $(\mathrm{w} / \mathrm{v})$.

\begin{tabular}{|c|c|c|c|}
\hline \multirow{2}{*}{$\begin{array}{c}\text { Strain } \\
\text { (plasmid) }\end{array}$} & \multirow{2}{*}{$\begin{array}{l}\text { Carbon } \\
\text { sources }\end{array}$} & \multicolumn{2}{|c|}{$\begin{array}{l}\text { Rate of } 4 \text {-MU formation }\left[\mu \mathrm{mol} \mathrm{min}^{-1}\right. \\
\left.(\mathrm{mg} \text { total cell protein })^{-1}\right] \text { from }\end{array}$} \\
\hline & & 4-MU(GlcNAc $)_{2}$ & 4-MU(GlcNAc $)_{3}$ \\
\hline TK24 & $\begin{array}{l}\text { none } \\
\text { chitin } \\
\text { chitin }+ \text { glucose }\end{array}$ & $\begin{array}{c}2.9 \\
190 \\
0 \cdot 11\end{array}$ & $\begin{array}{c}1.9 \\
140 \\
0.07\end{array}$ \\
\hline TK24 (pEMJ1) & $\begin{array}{l}\text { none } \\
\text { chitin } \\
\text { chitin }+ \text { glucose }\end{array}$ & $\begin{array}{c}11 \\
650 \\
2 \cdot 9\end{array}$ & $\begin{array}{l}2 \cdot 8 \\
96 \\
0 \cdot 5\end{array}$ \\
\hline TK24 (pEMJ5) & $\begin{array}{l}\text { none } \\
\text { chitin } \\
\text { chitin }+ \text { glucose }\end{array}$ & $\begin{array}{c}2 \cdot 3 \\
410 \\
0 \cdot 23\end{array}$ & $\begin{array}{l}0 \cdot 8 \\
55 \\
0 \cdot 17\end{array}$ \\
\hline TK24 (pEMJ7) & $\begin{array}{l}\text { none } \\
\text { chitin } \\
\text { chitin + glucose }\end{array}$ & $\begin{array}{c}2 \cdot 8 \\
93 \\
0 \cdot 2\end{array}$ & $\begin{array}{c}4 \cdot 5 \\
550 \\
0 \cdot 3\end{array}$ \\
\hline
\end{tabular}


The cloned genes were also expressed when carried on pIJ486. pIJ486 has a terminator located just upstream of the cloning site which prevents the readthrough of vector promoters into the cloned fragment (Hopwood et al., 1985). This result and the regulated expression of the cloned genes indicate that the cloned fragments of DNA probably contained the natural promoter signal of the chitinase genes.

\section{Discussion}

In an attempt to clone chitinase genes from S. lividans 66, three recombinant plasmids were obtained which, between them, produced four chitinases, A, B, C, and D. Recombinant plasmids pEMJ1 and pEMJ5 specify the synthesis of chitinases A and B, respectively, while the other two chitinases $C$ and $D$ are encoded on plasmid pEMJ7. The production of two chitinases by one plasmid can be explained either by the presence of two chitinase genes on the plasmid, or by conversion of one chitinase to the other chitinase. The generation of a derivative chitinase by proteolytic degradation has been observed in the chitinase system of Bacillus circulans (Watanabe et al., 1990). The similarities in some of the properties of chitinases $C$ and $D$ support the possibility that chitinase $\mathrm{D}$ is generated from chitinase $\mathrm{C}$. Determination of the $\mathrm{N}$-terminal sequence of both chitinase proteins and of the nucleotide sequences of the cloned DNA fragments will resolve this issue.

Initially, we tried to isolate chitinase-negative mutants of $S$. lividans 66 by treating spores with $N$-methyl- $N^{\prime}-$ nitro- $N$-nitrosoguanidine (NTG). After repeated treatment, some strains showed very low chitinase production. However, chitinase-negative mutants could not be obtained. This failure was probably due to the presence of multiple genes for chitinase in $S$. lividans. We therefore used $S$. lividans TK64 as a host, and selected chitinase-positive clones by measuring the increase in chitinase production on colloidal chitin plates supplemented with thiostrepton. Since the chitinase activity of the clones obtained was more than 10-fold higher than that of the parent strain $S$. lividans TK64, clones could easily be distinguished both on plates and in liquid culture. The low chitinase production of $S$. lividans TK64, lower than that of strain TK24, was helpful.

The possibility that the cloned sequences were regulatory rather than structural genes, was ruled out for the following reasons. Firstly, each clone synthesized one particular chitinase almost exclusively. Secondly, when $S$. coelicolor was transformed with a given plasmid, it secreted the same chitinase as that produced in $S$. lividans. Thirdly, when the inserted fragment of DNA from each hybrid plasmid was subcloned into pUC18 or 19 and introduced into $E$. coli, the transformed cells showed chitinase activities which were either dependent or independent of the pUC lac promoter.

All the cloned chitinase genes were induced in the presence of chitin and repressed in the presence of glucose. However, it is unlikely that the regulatory genes involved in the induction and repression of chitinase genes were cloned together with structural genes, because substantial homology was not observed between the cloned fragments of DNA. Furthermore, the expression of each gene was independent of the presence of the others. Genes encoding production of extracellular enzymes, such as agarase, amylase, and xylanase, have been cloned in S. lividans (Kendall \& Cullum, 1984; Mondou et al., 1986; Virolle \& Bibb, 1988). Expression of these genes is also induced by substrate, and repressed by glucose. It is suggested, therefore, that genomic genes regulate the expression of the cloned genes for chitinase. Although repression by glucose in $S$. coelicolor has been shown to be dependent upon a functional gene for glucose kinase, the exact mechanism of regulation of synthesis of extracellular enzymes remains to be elucidated (Virolle \& Bibb, 1988). Chitinase genes of $S$. lividans were also shown not to constitute a single operon.

The elution profile from the anion-exchange chromatogram for the parent strain did not show peak II, which represents chitinase B (Figure $3 a$ ), whereas the transformant with plasmid pEMJ5 synthesized high levels of this chitinase. It is likely that the gene for chitinase B in the genome is transcribed at very low levels or not at all. However, it is also possible that the chitinase B production is dependent on growth stage, and that our use of a stationary culture for the purification of chitinase rendered the detection of chitinase $B$ in the parent strain difficult. Production of some bacterial chitinases has been reported to be growth-stage-dependent (Watanabe et al., 1990).

Although multiple forms of bacterial chitinases have been reported by some authors (Jones et al., 1986; Robbins et al., 1988; Watanabe et al., 1990), the function of the multiple enzymes is still unclear. Their presence may be explained in part by the observed differences in the properties of chitinases A, B, and C. The differences in mode of action against 4-MU substrates suggest that the enzymes may act synergistically on native chitin. When the factors that control the expression of the individual genes are understood, we may be better able to assess the function of each individual chitinase.

This work was supported in part by a Grant-in-Aid (Bio Media Program) from the Ministry of Agriculture, Forestry and Fisheries of Japan (BMP 90-III-2-5). 


\section{References}

Berger, L. R. \& ReYnolds, D. M. (1958). The chitinase system of a strain of Streptomyces griseus. Biochimica et Biophysica Acta 29, 522 534.

BEYER, M. \& DiEKMANN, H. (1985). The chitinase system of Streptomyces sp. ATCC 11238 and its significance for fungal cell wall degradation. Applied Microbiology Biotechnology 23, 140-146.

BOLLER. T. (1987). Hydrolytic enzymes in plant disease resistance. In Plant-Microbe Interactions, vol. 2, pp. 385-413. Edited by T. Kosuge and E. W. Nester. New York: Macmillan.

Chater, K. F., Hopwood, D. A., Kieser, T. \& Thompson, C. J. (1982). Gene cloning in Streptomyces. Current Topics in Microbiology and Immunology 96, 69-95.

Clarke, P. H. \& TraceY, M. V. (1956). The occurrence of chitinase in some bacteria. Journal of General Microbiology 14, 188-196.

Correa, J. U., Elango, N., Polancheck, I. \& Cabib, E. (1982). Endochitinase, a mannose-associated enzyme from Saccharomyces cerevisiae. Journal of Biological Chemistry 257, 1392-1397.

Elango, N., Correa, J. V. \& Cabib, E. (1982). Secretory character of yeast chitinase. Journal of Biological Chemistry 257, 1398-1400.

Fuchs, R. L., Macpherson, S. A. \& Drahos, D. J. (1986). Cloning of a Serratia marcescens gene encoding chitinase. Applied and Environmental Microbiology 51, 504-509.

GoOdAy, G. W. (1990). The ecology of chitin decomposition. Advances in Microbial Ecology 11, 387-430.

Hara, S., Yamamura, Y., Fujil, Y., Mega, T. \& Ikenaka, T. (1989). Purification and characterization of chitinase produced by Streptomyces erythraeus. Journal of Biochemistry 105, 484-489.

Hopwood, D. A., Bibb, M. J., Chater, K. F., Kieser, T., Bruton, C. J., Kieser, H. M., Lydiate, D. L., Smith, C. P., Ward, J. M. \& SCHREMPF, H. S. (1985). Genetic Manipulation of Streptomyces - a Laboratory Manual. Norwich, UK: John Innes Foundation.

Jones, J. D. G., Grady, K. L., Suslow, T. V. \& Bedbrook, J. R. (1986). Isolation and characterization of genes encoding two chitinase enzymes from Serratia marcescens. EMBO Journal 5, 467473.

Joshi, S., Kozlowski, M., Selvaraj, G., Iyer, V. N. \& Davies, R. W. (1988). Cloning of the genes of the chitin-utilization regulon of Serratia liquefaciens. Journal of Bacteriology 170, 2984-2988.

Kamei, K., Yamamura, Y., Hara, S. \& Ixenaka, T. (1989). Amino acid sequence of chitinase from Streptomyces erythraeus. Journal of Biochemistry 105, 979-985

Kendall, K. \& Cullum, J. (1984). Cloning and expression of an extracellular-agarase gene from Streptomyces coelicolor A3(2) in Streptomyces lividans 66. Gene 29, 315-321.

KIESER, T. (1984). Factors affecting the isolation of cccDNA from Streptomyces lividans and Escherichia coli. Plasmid 12, 19-36.
LingapPA, Y. \& Lockwood, J. L. (1962). Chitin media for selective isolation and culture of Actinomycetes. Phytopathology 52, 317-323.

Maniatis, T., Fritsch, E. F. \& Sambrook, J. (1982). Molecular Cloning: a Laboratory Manual. Cold Spring Harbor, NY: Cold Spring Harbor Laboratory.

Mondou, F., Shareck, F., Morosoli, R. \& Kluepfel, D. (1986) Cloning of xylanase gene of $S$. lividans. Gene 49, 323-329.

MonReal, J. \& ReEse, E. T. (1969). The chitinase of Serratia marcescens. Canadian Journal of Microbiology 15, 689-696.

Morano, J., Polancheck, I., Duran, A. \& Cabib, E. (1979). An endochitinase from wheat germ: activity on nascent and preformed chitin. Journal of Biological Chemistry 254, 4901-4907.

Murakami, T., HolT, T. \& Thompson, C. (1988). The regulation of a thiostrepton-inducible promoter in Streptomyces lividans. In Biology of Actinomycetes '88, pp. 371-373. Edited by Y. Okami, T. Beppu \& H. Ogawara. Tokyo: Japan Scientific Society Press.

REYNOLDS, D. M. (1954). Exocellular chitinase from a Streptomyces sp. Journal of General Microbiology 11, 150-159.

RoBerts, R. L. \& CABIB, E. (1982). Serratia marcescens chitinase: one step purification and use for the determination of chitin. Analytical Biochemistry 127, 402-412.

Roberts, W. K. \& Selitrennikoff, C. P. (1988). Plant and bacterial chitinases differ in antifungal activity. Journal of General Microbiology 134, 169-176.

Robbins, P. W., Albright, C. \& Benefield, B. (1988). Cloning and expression of a Streptomyces plicatus chitinase (chitinase-63) in Escherichia coli. Journal of Biological Chemistry 263, 443-447.

Skujins, J. J., Braal, L. \& Maclaren, A. D. (1962). Characterization of phosphatase in a terrestial soil sterilized with an electron beam. Enzymologia 25, 125-133.

Tominaga, Y. \& Tsujisaka, Y. (1976). Purification and some properties of two chitinases from Streptomyces orientalis which lyse Rhizopus cell wall. Agricultural and Biological Chemistry 40, 23252333.

Yanisch-Perron, C., Vieira, J. \& Messing, J. (1985). Improved M13 phage cloning vectors and host strains: nucleotide sequences of the M13 mpl8 and pUC19 vectors. Gene 33, 103-119.

VIROLLE, M.-J. \& BIBB, M. J. (1988). Cloning, characterization and regulation of an alpha-amylase gene from Streptomyes limosus. Molecular Microbiology 2, 197-208.

Watanabe, T., Oyanagi, W.. Suzuki, K. \& Tanaka, H. (1990). Chitinase system of Bacillus circulans WL12 and importance of chitinase A 1 in chitin degradation. Journal of Bacteriology 172, 40174022.

Wortman, A. T., Somerville, C. C. \& Colwell, R. R. (1986). Chitinase determinants of Vibrio vulnificus: gene cloning and application of a chitinase probe. Applied and Environmental Microbiology 52, 142-145. 